\title{
Prevalence of Circulating Tumor Cells in Localized Prostate Cancer
}

\author{
Kiranpreet K. Khurana ${ }^{\mathrm{a}} \quad$ Ronald Grane $^{\mathrm{b}} \quad$ Ernest C. Borden ${ }^{\mathrm{b}} \quad$ Eric A. Klein ${ }^{\mathrm{a}}$ \\ aGlickman Urological \& Kidney Institute and ${ }^{\mathrm{b} T a u s s i g ~ C a n c e r ~ C e n t e r, ~ C l e v e l a n d ~ C l i n i c, ~ C l e v e l a n d, ~ O h i o, ~ U S A ~}$
}

\section{Key Words}

Prostatic cancer $\cdot$ Radical prostatectomy •

Circulating tumor cells

\begin{abstract}
Background: Circulating tumor cells (CTC) predict overall survival in patients with metastatic prostate cancer. The objective of this study is to measure CTC before radical prostatectomy in intermediate- and high-risk prostate cancer patients. Materials and Methods: The study accrued 12 patients and 10 provided adequate peripheral blood sample. Blood was drawn preoperatively and assayed for CTC using the CellSearch system. Patients were categorized as CTC positive ( $\geq 1$ CTC) or CTC negative (no CTC). Results: Median age was 64.5 years (range $49-77$ years), median prostate specific antigen was $7.4 \mathrm{ng} / \mathrm{ml}$ (range $5.7-25.7 \mathrm{ng} / \mathrm{ml}$ ). Seven patients had intermediate-risk and 3 patients had high-risk prostate cancer. One patient was found to be CTC positive. Conclusions: Our pilot study shows that CTC are rare in patients with clinically localized disease despite intermediateto high-risk features. CTC may not be the optimal marker to predict prognosis or detect residual disease after radical prostatectomy.

Copyright $\odot 2013$ S. Karger AG, Basel
\end{abstract}

\section{Introduction}

Circulating tumor cells (CTC) in prostate cancer have been detected and predict overall survival in patients with metastatic prostate cancer [1-3], but have not been extensively studied in men with earlier stage disease. Detection of CTC may help in characterizing these cells and clarifying the role of tumor shedding in men with intermediate- and high-risk prostate cancer [4]. CTC detection may be a useful prognostic factor in management of these men. The CellSearch system for CTC detection works by using antibodies joined to microscopic iron particles (ferrofluid). These antibody/ferrofluid combinations attach to CTCs. Powerful magnets draw CTCs out of the blood sample. They are then stained with additional biomolecules and chemicals so they can be positively identified as CTCs. This system has been approved by the Federal Drug Administration for enumeration of CTC in patient with metastatic castration-resistant prostate cancer [2] as well as in metastatic breast and colorectal cancers.

CTC detected by the CellSearch system are epithelial cells that express transmembrane glycoprotein epithelial cell adhesion molecule (EpCAM) and cytokeratins. These cells are thought to represent tumor cells as they are found in cancerous conditions, but not in non-cancerous conditions or healthy subjects [5]. However, anti-EpCAM systems may detect circulating epithelial cells in benign conditions as seen in one study which found $0-19 \%$ rate of circulating epithelial cells detection in

Kiranpreet Khuran

9500 Euclid Avenue, Q10 Cleveland, OH 44120 (USA)

E-Mail khurank@ccf.org 
benign colon disease [6]. Similarly, another study found that the circulating cells detected by monoclonal antibody directed against prostate specific antigen (PSA) and P504S in prostate biopsy samples were PSA-positive, and P504S-negative in benign prostate conditions [7], whereas in none of the cancerous biopsies were PSA-positive and P504S-negative. P504S is a biomarker used to differentiate between benign and malignant disease [8]. Therefore, not all circulating cells in blood samples detected by anti-epithelial biomarkers may be cancerous, and more specific biomarkers may be necessary to accurately differentiate between circulating cells with malignant versus non-malignant potential. We sought to determine whether the CellSearch system could detect circulating cells in localized prostate cancer. The objective of this prospective study was to measure the rate of CTC detection before radical prostatectomy in patients with intermediate- and high-risk prostate cancer as defined by the D'Amico criteria [9].

\section{Materials and Methods}

The study was designed as a prospective, pilot study and approved by the institutional review board. All subjects gave informed consent prior to study enrollment. Planned study accrual was 10 evaluable patients. Patients were eligible if they met the following inclusion criteria: age $>18$, pathological diagnosis of intermediate- or high-risk prostate cancer, and scheduled for radical prostatectomy. Patients were excluded if they had any of the following: prior prostate cancer directed therapy or medication, immunosuppressive medications at any time, other malignancies (except non-melanoma skin cancer), or history of prostate biopsy, infection, inflammation, or manipulation within 14 days of blood sample collection.

Study subjects underwent $10 \mathrm{ml}$ blood draw preoperatively which were assayed for CTC counts. Patients were categorized as either CTC positive ( $1 \mathrm{CTC} / 7.5 \mathrm{ml}$ of blood) or CTC negative (0 CTC/7.5ml of blood) based on their CTC counts. The optimal cutoff for CTC detection is uncertain. In most studies with metastatic cancers, a cutoff of 3 or 5 per milliliter is considered positive. The cutoff of $1 \mathrm{CTC}$, which is lower than the FDA-approved cutoff, was chosen because localized prostate cancer is likely to have fewer CTC in the peripheral blood than castrate-resistant metastatic prostate cancer. The only study done in localized prostate cancer patients showed that CTC positivity rate was $21 \%$, of which the majority of patients only had 1 CTC detected [10]. CTC of 1 is also the lowest limit of detection for the assay. In this pilot study of intermediate- and high-risk prostate cancer, $20 \%$ detection rate was determined to be clinically relevant. This rate was chosen based on the aforementioned study in patients with localized prostate cancer who had a $21 \%$ rate of CTC detection.

One 10-ml Cell Saver tube of peripheral blood was collected and sent to the Circulating Tumor Cell Core Laboratory. Samples were maintained at room temperature and processed within 72 hours after collection. CTCs were isolated and enumerated at each blood draw using the CellSearch System (Veridex LLC, Raritan, NJ), which detects CTCs using EpCAM antibodies to immunomagnetically enrich for epithelial cells and then a mixture of dye-conjugated antibodies to cytokeratins 8,18 , and 19 and CD45 for detection. $7.5 \mathrm{ml}$ of blood were mixed with $6.5 \mathrm{ml}$ of buffer, centrifuged at $800 \mathrm{x} \mathrm{g}$ for 10 minutes, and then placed on the CellPrep system. After aspiration of the plasma and buffer layer by the instrument, ferrofluids were added. After the incubation period and subsequent magnetic separation, unbound cells and remaining plasma were aspirated. The staining reagents were then added in conjunction with a permeabilization buffer to fluorescence label the immunomagnetically labeled cells. After incubation on the system, the magnetic separation was repeated, and excess staining reagents were aspirated. In the final processing step, the cells were re-suspended in the MagNest Cell Presentation Device (Veridex LLC). This device consists of a chamber and two magnets that orient the immunomagnetically labeled cells for analysis using the CellSpotter Analyzer. CTCs were defined as nucleated cells lacking CD45 and expressing cytokeratin. All assays were done by trained operators who were blinded to patient characteristics.

\section{Results}

A total of 12 patients were enrolled. Two patients were excluded due to insufficient blood sample collection. Among the 10 evaluable patients, 7 had intermediate-risk disease and 3 had high-risk disease per D'Amico criteria [9]. Median age was 64.5 years (range $49-77$ years), and median PSA was $7.4 \mathrm{ng} / \mathrm{ml}$ (range $5.7-25.7 \mathrm{ng} / \mathrm{ml}$ ). Median time between biopsy and CTC measurement was 79.5 days (range 17-261 days). All patients had Gleason grade 7 or higher disease on final pathology, while 5 had a pathological stage of T2c (organ confined bilateral disease) and 5 had stage T3a (extraprostatic extension) (table1).

One out of 10 patients (patient number 9) was found to be CTC positive $(\mathrm{CTC}=1)$. The intervals between prostate biopsy and blood sample collection, and rectal exam and blood sample collection were 165 and 107 days, respectively. Therefore, the CTC positivity rate in this intermediate- and high-risk prostate cancer cohort was $10 \%$.

\section{Discussion}

The data from our pilot study shows that using an FDA-approved system that reliably detects CTCs in men with metastatic prostate cancer; CTCs are rarely detected in patients with clinically localized disease despite intermediate- to high-risk features. The results suggest that release of CTCs by these early stage tumors is be- 
Table 1. Clinical and pathological characteristics of study patients

\begin{tabular}{|c|c|c|c|c|c|c|c|}
\hline Patient & Age (years) & PSA (ng/ml) & Clinical stage & Biopsy Gleason & $\begin{array}{l}\text { Days between } \\
\text { biopsy and CTC } \\
\text { measurement }\end{array}$ & Pathology Gleason & Pathological stage \\
\hline 2 & 66 & 16.23 & $\mathrm{~T} 1 \mathrm{c}$ & $3+4$ & 98 & $3+4$ & $\mathrm{~T} 2 \mathrm{c}$ \\
\hline 3 & 64 & 5.71 & $\mathrm{~T} 1 \mathrm{c}$ & $4+3$ & 141 & $3+4$ & $\mathrm{~T} 2 \mathrm{c}$ \\
\hline 6 & 77 & 6.5 & $\mathrm{~T} 1 \mathrm{c}$ & $4+5$ & 37 & $5+4$ & $\mathrm{~T} 2 \mathrm{c}$ \\
\hline 7 & 62 & 18.4 & $\mathrm{~T} 2 \mathrm{a}$ & $3+4$ & 23 & $3+4$ & T3a \\
\hline 8 & 49 & 12.3 & $\mathrm{~T} 1 \mathrm{c}$ & $3+4$ & 58 & $5+4$ & T3a \\
\hline 9 & 62 & 7.3 & $\mathrm{~T} 1 \mathrm{c}$ & $4+3$ & 165 & $4+3$ & $\mathrm{~T} 2 \mathrm{c}$ \\
\hline 10 & 59 & 5.84 & $\mathrm{~T} 1 \mathrm{c}$ & $3+4$ & 261 & $3+4$ & $\mathrm{~T} 2 \mathrm{c}$ \\
\hline
\end{tabular}

yond the limit of detection using the CellSearch system and that such technology cannot be used for identifying CTCs that might confer a higher risk of recurrence in this cohort of patients treated by radical prostatectomy. This system may not be the best option for detecting these cells. For example, in breast cancer, EpCAM-negative CTCs are detected in $34 \%$ of patients, and this may be due to the transition of some epithelial cells to mesenchymal-type cells $[11,12]$.

Two prior studies used the CellSearch system in patients with clinically localized prostate cancer. One study compared 97 men with localized prostate cancer to control group of men with increased PSA and negative extended prostate biopsy [10]. They found CTCs in 21 and $20 \%$ of experimental and control groups, respectively. Detection of CTCs did not correlate with tumor volume, pathological stage, and Gleason. They concluded that CTCs do not have a predictive prognostic value in this cohort of patients. The control group in this study may not be the most optimal group as some men may have had occult prostate cancer not yet detected. Conversely, a study from Spain used the CellSearch system to detect and enumerate CTCs in localized and metastatic colon, breast, and prostate cancer [4]. They found CTCs in all 26 men with localized prostate cancer and all 24 men with metastatic prostate cancer.

The detection rate in our study was $10 \%$, while the study by Davis et al. [10] detected CTCs in $20 \%$ of men with localized prostate cancer. These numbers are similarly low confirming the low detection rate of CTCs in this patient cohort. It is possible that with a larger sam- ple size, the detection rate of CTCs by the CellSearch system may be higher. The study by Maestro et al. [4] found CTCs in all men, however "localized" cancer was defined as any cancer with or without lymph node involvement but less than M1. Further staging details were not provided in this paper. It is not known whether these men truly had localized prostate cancer, and how many men had lymph node positive disease.

Other methods have been used to detect micrometastasis and predict clinical outcome. These methods are un-validated, experimental, and have had mixed results. One of the most common methods of detecting CTCs is reverse transcriptase polymerase chain reaction (RTPCR) of PSA messenger ribonucleic acid (mRNA). A study by Moreno et al. [13] used RT-PCR of PSA mRNA in prostate cancer patients. This study found PSA mRNA in 4 out of 12 or $33 \%$ of patients. However these patients had nodal positive or metastatic disease. PSA mRNA was not detected in patients with localized prostate cancer. A French study found that RT-PCR of PSA mRNA was positive in 33 of 99 (33\%) patients with clinically localized prostate cancer [14]. This was associated with PSA $>15 \mathrm{ng} / \mathrm{ml}$ at diagnosis, development of relapse, metastasis, and time to metastasis. Another study did RT-PCR of PSA mRNA on bone marrow of patients with localized prostate cancer. This study found that detection of PSA mRNA in bone marrow was not predictive of disease-free survival after adjusting for PSA level [15]. A Belgian study investigated men with and without biochemical recurrence after radical prostatectomy [16]. RT-PCR of PSA mRNA was positive in $1 / 45$ 
(2\%) patients without PSA recurrence and 19/55 (34\%) patients with PSA recurrence. Positive RT-PCR status correlated with shorter PSA doubling time, but did not correlate with pathological stage, Gleason grade, or PSA at time of PCR. The difference between this and earlier studies is that this study selected for men who already had biochemical recurrence. Another study found that real-time quantitative PCR of PSA mRNA was 3.73 times higher in patients with clinically localized prostate cancer than in control patients [17]. This study did not find any correlation of positivity to pathological stage, PSA, or Gleason. They concluded that there was no advantage of using RT-PCR before radical prostatectomy to predict adverse pathological features. The role of detecting PSA mRNA in patients with localized disease has not been well defined, and it is unclear whether it has any diagnostic, therapeutic, or prognostic value.

Another method investigated in a study by Ellis et al. [18] is antibody-coated paramagnetic microparticle technology, which is used for positive and negative selection of cells in bone marrow and peripheral blood of patients with localized prostate cancer. Further details of patient and disease characteristics were not provided, so the stage, grade, and PSA values of the patients included in this study are unknown. Anti-CD45 and anti-CD61 antibodies were used for negative selection and anti-human epithelial antigen (Ber-EP4) was used for positive selection. They found that PSA-expressing epithelial cells were present in 54\% of bone marrow (60 out of 126) and $24 \%$ of peripheral blood samples (33 out of 138) before radical prostatectomy. The authors state that there was no difference in clinical features between patients who did or did not have these cells. This method requires further study to assess its clinical utility.

Due to low number of CTCs in peripheral blood of patients with early stage prostate cancer, methods with increased detection rate are needed. Scott et al. [19] used a CTC-Chip to improve the yield of CTCs. The CTCChip contains an array of 78,000 microposts which bind EpCAM-expressing CTCs. The Chip is then stained for nucleic acids and PSA. The CTC-Chip is imaged in multiple dimensions using an automated microscopic platform. Images are analyzed using an image processor to allow precise localization of DNA and PSA signals. They detected CTCs in 8 of 19 (42\%) patients with localized prostate cancer. Notably, the number of CTCs detected ranged from 38 to 222 CTCs per ml. This method requires further investigation and optimization.

Another method of detecting CTC is by using telomerase activity. In a study of 107 men, peripheral blood mononuclear cells were isolated and epithelial cell-specific antigen antibody (BerEP4) coated beads were used to identify epithelial cells. They were further analyzed for telomerase activity. This study found CTC in 19 of 24 (79\%) patients with advanced prostate cancer, 55 of 70 (79\%) patients with localized prostate cancer, and 3 of $13(23 \%)$ patients with undetectable PSA at least 1 year after radical prostatectomy [20]. A study by Murray et al. [21] found primary circulating prostate cells in $75.3 \%$ of 77 patients using anti-PSA antibody and further subclassified using anti-CD82 antibody. Men with circulating prostate cells (PSA+ CD82-) had a relative risk of bone marrow micrometastasis of 36 times more than men who were circulating prostate cells negative and 7 times those who were PSA+ CD82+. Subclassification of detected epithelial cells may be useful in accurately identifying circulating tumor cells.

There is a great need to differentiate men with locally advanced prostate cancer who are cured by radical prostatectomy and those who have residual disease resulting in eventual biochemical failure. CTCs may have a potential role in early spread of prostate cancer. Detection of CTCs may help select men who benefit from adjuvant treatment. Newer methods including the CTC-Chip seem promising. Further studies are needed to investigate and develop methods with high sensitivity and specificity to detect residual disease after definitive surgical treatment to guide adjuvant therapy.

In summary, our pilot study shows that CTCs are rarely detected in patients with clinically localized disease despite intermediate- to high-risk features. Due to low number of CTCs in peripheral blood of patients with early stage prostate cancer, CTCs may not be the optimal marker to predict prognosis in men with intermediateand high-risk prostate cancer. However, more sensitive methods to detect CTCs are available, and should be investigated. 


\section{References}

-1 Danila DC, Heller G, Gignac GA, Gonzalez-Espinoza R, Anand A, Tanaka E, Lilja H, Schwartz L, Larson S, Fleisher M, Scher HI: Circulating tumor cell number and prognosis in progressive castration-resistant prostate cancer. Clin Cancer Res 2007;13:7053-7058.

$\checkmark 2$ de Bono JS, Scher HI, Montgomery RB, Parker C, Miller MC, Tissing H, Doyle GV, Terstappen LW, Pienta KJ, Raghavan D: Circulating tumor cells predict survival benefit from treatment in metastatic castration-resistant prostate cancer. Clin Cancer Res 2008; 14:6302-6309.

-3 Scher HI, Jia X, de Bono JS, Fleisher M, Pienta KJ, Raghavan D, Heller G: Circulating tumour cells as prognostic markers in progressive, castration-resistant prostate cancer: a reanalysis of IMMC38 trial data. Lancet Oncol 2009;10:233-239.

-4 Maestro LM, Sastre J, Rafael SB, Veganzones SB, Vidaurreta M, Martin M, Olivier C, de la Orden VB, Garcia-Saenz JA, Alfonso R, Arroyo M, Diaz-Rubio E: Circulating tumor cells in solid tumor in metastatic and localized stages. Anticancer Res 2009;29:48394843.

5 Allard WJ, Matera J, Miller MC, Repollet M, Connelly MC, Rao C, Tibbe AG, Uhr JW, Terstappen LW: Tumor cells circulate in the peripheral blood of all major carcinomas but not in healthy subjects or patients with nonmalignant diseases. Clin Cancer Res 2004; 10:6897-6904.

6 6 Pantel K, Deneve E, Nocca D, Coffy A, Vendrell JP, Maudelonde T, Riethdorf S, Alix-Panabieres C: Circulating epithelial cells in patients with benign colon diseases. Clin Chem 2012;58:936-940.

$\checkmark 7$ Murray NP, Reyes E, Badinez L, Orellana $\mathrm{N}$, Fuentealba C, Olivares R, Porcell J, Duenas R: Circulating prostate cells found in men with benign prostate disease are P504S negative: clinical implications. J Oncol 2013; 2013:165014. $\checkmark 8$ Beach R, Gown AM, De Peralta-Venturina MN, Folpe AL, Yaziji H, Salles PG, Grignon DJ, Fanger GR, Amin MB: P504S immunohistochemical detection in 405 prostatic specimens including 376 18-gauge needle biopsies. Am J Surg Pathol 2002;26:15881596.

-9 D'Amico AV, Whittington R, Malkowicz SB, Schultz D, Blank K, Broderick GA, Tomaszewski JE, Renshaw AA, Kaplan I, Beard CJ, Wein A: Biochemical outcome after radical prostatectomy, external beam radiation therapy, or interstitial radiation therapy for clinically localized prostate cancer. JAMA 1998;280:969-974.

10 Davis JW, Nakanishi H, Kumar VS, Bhadkamkar VA, McCormack R, Fritsche HA, Handy B, Gornet T, Babaian RJ: Circulating tumor cells in peripheral blood samples from patients with increased serum prostate specific antigen: initial results in early prostate cancer. J Urol 2008;179:2187-2191.

11 Mikolajczyk SD, Millar LS, Tsinberg P, Coutts SM, Zomorrodi M, Pham T, Bischoff FZ, Pircher TJ: Detection of EpCAM-negative and cytokeratin-negative circulating tumor cells in peripheral blood. J Oncol 2011;2011:252361.

12 Raimondi C, Gradilone A, Naso G, Vincenzi B, Petracca A, Nicolazzo C, Palazzo A, Saltarelli R, Spremberg F, Cortesi E, Gazzaniga $\mathrm{P}$ : Epithelial-mesenchymal transition and stemness features in circulating tumor cells from breast cancer patients. Breast Cancer Res Treat 2011;130:449-455.

13 Moreno JG, Croce CM, Fischer R, Monne M, Vihko P, Mulholland SG, Gomella LG: Detection of hematogenous micrometastasis in patients with prostate cancer. Cancer Res 1992;52:6110-6112.

14 Mejean A, Vona G, Nalpas B, Damotte D, Brousse N, Chretien Y, Dufour B, Lacour B, Brechot C, Paterlini-Brechot P: Detection of circulating prostate derived cells in patients with prostate adenocarcinoma is an independent risk factor for tumor recurrence. J Urol 2000;163:2022-2029.
15 Wood DP Jr, Banerjee M: Presence of circulating prostate cells in the bone marrow of patients undergoing radical prostatectomy is predictive of disease-free survival. J Clin Oncol 1997; 15:3451-3457.

16 Tombal B, Van Cangh PJ, Loric S, Gala JL: Prognostic value of circulating prostate cells in patients with a rising PSA after radical prostatectomy. Prostate 2003;56:163-170.

17 Llanes L, Ferruelo A, Lujan M, Pascual C, Garcia-Mediero JM, Berenguer A: Quantitative real-time reverse transcription: polymerase chain reaction of prostate-specific antigen (PSA) for detection of circulating prostatic cells in patients with clinically localized prostate cancer. Prostate Cancer Prostatic Dis 2005;8:248-252.

18 Ellis WJ, Pfitzenmaier J, Colli J, Arfman E, Lange PH, Vessella RL: Detection and isolation of prostate cancer cells from peripheral blood and bone marrow. Urology 2003;61: 277-281.

19 Stott SL, Lee RJ, Nagrath S, Yu M, Miyamoto DT, Ulkus L, Inserra EJ, Ulman M, Springer S, Nakamura Z, Moore AL, Tsukrov DI, Kempner ME, Dahl DM, Wu CL, Iafrate AJ, Smith MR, Tompkins RG, Sequist LV, Toner M, Haber DA, Maheswaran S: Isolation and characterization of circulating tumor cells from patients with localized and metastatic prostate cancer. Sci Transl Med 2010;2: $25 \mathrm{ra} 23$.

20 Fizazi K, Morat L, Chauveinc L, Prapotnich D, De Crevoisier R, Escudier B, Cathelineau X, Rozet F, Vallancien G, Sabatier L, Soria JC: High detection rate of circulating tumor cells in blood of patients with prostate cancer using telomerase activity. Ann Oncol 2007; 18:518-521.

21 Murray NP, Reyes E, Badinez L, Orellana N, Duenas R, Fuentealba C: Detection and characteristics of primary circulating prostate cells; association with micrometastasis and implications for surgical treatment of men with prostate cancer. Arch Esp Urol 2010;63: 345-353. 